\title{
ECCLESIASTICAL AND POLITICAL LEADERSHIPS IN ONE ARMPIT: RECONSTRUCTING THE MEMORY OF THOMAS KALUME (1925-75)
}

\section{Julius Mutugi Gathogo}

Research Institute for Theology and Religion, University of South Africa

Kenyatta University, Mombasa campus

jgathogom@yahoo.com

\section{ABSTRACT}

As Kenya celebrated her $52^{\text {nd }}$ independence day on 12 December 2015, the name of Thomas Johnson Kuto Kalume (1925-75) re-appeared as a great hero whom Kenyans have always wanted to forget. Indeed, he was a Kenyan politician and the first clergyman to be elected as a Member of Parliament (MP) in the history of the National Assembly. Rev. Kalume was a composer and coproducer of the Kenyan national anthem, which was recorded in English and Swahili in September 1963 and inaugurated by Kenya's founding President, Jomo Kenyatta, at Uhuru Gardens on 12 December 1963 during independence celebrations. Critically important is that Kalume is the second Anglican Kenyan to obtain a university degree in theology after John Mbiti. He was followed by Henry Okullu and David Gitari who emerged fourth. This article sets out to retrace Kalume's pedigree, theology, and philosophy, as he navigated through troubled waters in the young republic of Kenya. What led to his early death on

\section{UNISA $\cong$}


15 March 1975 after having served only one parliamentary term (1969-74)? What motivated him to first seek ecclesiastical leadership and later elective politics that drove him to Kenya's second parliament? How did he view the service to God and humanity? How did he juxtapose ecclesiastical and political leaderships without losing his gospel constituency? What lessons does Kalume have for the $21^{\text {st }}$ century Africa, particularly with regard to keeping ecclesiastical and political leaderships in one armpit? Was Kalume's case rooted in African religious heritage; a phenomenon where there is no dichotomisation between the secular (politics) and the sacred (religion)? To this end, the article focuses mainly on the manner in which the memory of Kalume has been celebrated and/or reconstructed half a century after Kenya's independence. By use of expost facto design, a phenomenon where variables have already occurred and are not manipulated by the researcher, the article has endeavoured to retrieve Kalume's societal contribution largely through archival and oral sources.

Keywords: Church and politics; ecclesiastical leadership; political leadership; Thomas Kalume

\section{INTRODUCTION}

In his book, Troubled but not destroyed, Archbishop David Gitari (1937-2013) talks about his troubled life - a life characterised by difficult challenges. That is, troubles from his family, school, college, university, ecclesiastical leadership, and in the political life of the Kenyan nation where he was a major player in the socioecclesial scene. ${ }^{1}$ Likewise, the case of Thomas Johnson Kuto Kalume has similar characteristics; a life full of troubles but ironically with great triumphs. Kalume, who died while relatively young, left before he published his own memoirs, unlike Gitari and Bishop Henry Okullu; hence he rested with a lot of socio-ecclesial information that needed to be narrated to the larger society. In his recollections, Gitari recalls his ordination to priesthood, in early 1970s, which was full of troubles as the then Archbishop of the Anglican church of Kenya, Festo Habakkuk Olang', did not accept his offer of service, and was most likely working 'on the advice of his Archdeacon', the Ven. Ken Stovold. He goes on to say: '... at that time, I was only the fourth Anglican Kenyan to obtain a university degree in theology after Dr John Mbiti, the Revd Thomas Kalume (who became a Member of Parliament) and the Revd Henry Okullu (who at that time was the Editor of Target [Christian] Newspaper).' ${ }^{2}$

Nonetheless, both Gitari and Kalume are Kenyan heroes who did not despair as they wrestled with the vicissitudes of life; and as they gallantly sought to reform their respective conservative societies for the better. Interestingly, Kalume's diary records

1 Gitari, David. 2014. Troubled but not yet destroyed: Autobiography of Dr David M. Gitari, retired Archbishop of the Anglican Church of Kenya (McLean: Isaac Publishing, 2014).

2 Gitari, David. 2014. Troubled but not yet destroyed..., 31. 
all his life events from the year he was born in 1925 to 1974, a few months before he died on 15 March 1975. In turn, it shows his deep troubles that run throughout the whole gamut of his lifetimes, but which have relevance for the $21^{\text {st }}$ century Africa. Till he was free at last, Kalume would have shared St Paul's words and probably confess: 'We are troubled on every side, yet not distressed; we are perplexed, but not in despair' (2 Corinthians 4:8).

In view of the above, this article endeavours to focus mainly on the manner in which the memory of Thomas Johnson Kuto Kalume has been celebrated and/ or reconstructed half a century after Kenya's political independence (1963-2015). Clearly, as Kenya celebrated her $52^{\text {nd }}$ year of independence, on 12 December 2015, Kalume was remembered for seven key issues: 1) His roots as a member of the 'minority' Kambe ethnic group living among the predominantly Giriama ethnic group of the larger Miji-Kenda nation of Kenya; 2) His passion for education; 3) His contribution as a family man, which is indeed enviable to date; 4) Kalume's critical role in the composition of Kenya's national anthem. As Kenyans sang it heartily on 12 December 2015, Kalume's echoes could be felt; 5) His role as an Anglican clergyman (1964-1975) where he almost retained his office in the Anglican Church Malindi, even when he was a member of parliament (1969-74); 6) His contribution in the elective politics (1969-1974); and 7) His relevance for the post-colonial reconstruction of Kenya, and Africa at large.

\section{KALUME'S PEDIGREE}

As noted above, Kalume (1925-1975) traces his roots among the Kambe ethnic group of the larger Miji-Kenda nation of Kenya. In general, the Kambes, who are part of the nine ethnic groups that make up the Miji-Kenda community, are largely settled in Kambe, Kilifi County of Kenya. Geographically, the Miji-Kenda (meaning, the nine ethnic groups) are nine Bantu ethnic groups inhabiting the coast of Kenya, between the Sabaki and the Umba rivers, in an area stretching from the border with Tanzania in the south to the border near Somalia in the north. Historically, the MijiKenda peoples have derogatorily been called the Nyika (meaning, bush people) by outsiders. It includes the northern Miji-Kenda: the Chonyi, Kambe, Duruma, Kauma, Ribe, Rabai, Jibana, and Giriama. It also includes the southern Miji-Kenda, the Digo, who are also found in Tanzania due to their proximity to the common border.

Culturally, each of the Miji-Kenda groups has a sacred forest called kaya, which is a place of prayer. Significantly, 11 of the approximately 30 kaya forests have been inscribed together as UNESCO World Heritage Sites, the Sacred Miji-Kenda Kaya Forests. ${ }^{3}$ Miji-Kenda people are also known for creating wooden kigango funerary statues for which there is an illegal international market. Archaeologist Chapuruka

3 'Canadian fossil park, an Icelandic volcanic island and archipelago in Yemen among sites added to UNESCO World Heritage List,' UNESCO, July 7, 2008 (accessed 14 June 2015). 
Kusimba contends that the Miji-Kenda formerly resided in coastal cities, but later settled in Kenya's hinterlands to avoid submission to dominant Portuguese forces that were then in control. ${ }^{4}$ Mythological explanations have it that Shungwaya, situated to the north of the Tana River, is the actual origin of Miji-Kenda peoples who were Bantu migrants, and speakers of Sabaki Bantu languages. ${ }^{5}$ Each ethnic group has unique customs and a dialect of the Miji-Kenda language, although the dialects are similar to each other and to the Swahili language.

In the case of Kalume thus, his family originated from Kambe location though he was born in Bate village, Dagamra location, Malindi North district, in the Kilifi County of Kenya. In his diary, he explains that it is in 1882 that his grandfather, Kambuwa Mwambaru, migrated from Kambe location to Magarini, in Malindi North. Kambube had a son whom he named Tunje; while Tunje sired Kalume. Tunje had two wives. The first one was called Dama while the second one was Munyazi the mother of Kalume. Interestingly, Dama had only one son called Chivuga; while Munyazi had several children. Two of them were Raheli and Kandzje (the only one alive by 2015). By 2015, Kandzje, who was born in the 1930s was living in Bate, Malindi North. Kalume was the fourth born in the entire family but the third child of Munyazi. As a person who was brought up in a polygamous family, Kalume encountered the problems that go with it, a phenomenon that hardened his resolve to make a better family when he became of age (Tunje 10:06:15).

At this juncture, it is critical to ask: Why did his grandparents migrate from Kambe-Rabai to Bate-Malindi in 1882 ? First, there was a great famine called Njaaya Mwakisenge. In turn, Mwakisenge was a Seer who had predicted doom; a prophesy that ultimately happened. Hence Kambuwa Mwambaru, Kalume's grandfather and his family, moved to the north so as to look for food, and eventually settled in Malindi North. As they moved on, they first settled at Kauma village (now a location) where they established a home called Kambe-Katune (meaning the red Kambe because perhaps this place had red soil). They didn't stay at Kambe-Katune for a long time; as they left for Magarini (meaning beyond Malindi), or Malindi North; to a place where an Arab by name Suleimani had settled. In other words, they settled on his farm. Why? He had a big farm which was producing pigeon peas (kunde) and other foods; hence there was a lot of food on his farm. In the new dispensation, they experienced food security on this farm. This place is the current Bate; and from there, they saw no reason for returning to Kambe, and so Kalume began schooling at Bate primary school.

4 Gilbert, Erik and Reynolds, J.T. Africa in world history: From prehistory to the present (Pearson Education, 2008), 229.

5 Preucel, Robert W. and Mrozowski, Stephen A. Contemporary archaeology in theory: The new pragmatism (John Wiley \& Sons, 2011), 411. 


\section{Kalume as a herd's boy}

During his early school days, Kalume doubled as a pupil and herd's boy, tending to his father's goats. Before he formally joined school, he would take the goats to the school compound and listen to the ongoing teachings through the widow while he continued herding. When his father learnt that he was herding in the school compound, he got very angry, beat him up and warned him sternly never to do it again. Indeed, Tunje, his father, did not want to hear anything about 'European education', as he felt herding offered enough wealth that could sustain his polygamous family. As a result, Kalume's troubles forced him to run away from home and he went to live with his uncle John, who was renamed Said after converting to Islam. Indeed, it is Said, not Tunje, who took Kalume to school in 1938. With Tunje's rejection of socalled 'European education', it is no wonder that only one of Kalume's siblings got, at least, little education, and finally ended up as a police officer. Apart from Tunje having a big herd of goats and seeing it as sufficient for his family's up-keep, he was also reacting to the ordinary politics of the day, which saw school-going pupils as lazy people who were avoiding home chores, farm work and livestock herding, but instead preferred to just sit in class 'without doing substantial duties' (Tunje 10:06:15). Hence, in the locality, school-going as an 'occupation' was seen as the highest level of escapism and laziness.

\section{His early school days and teaching career}

In regard to his early education, Kalume began schooling in Bate primary school (1938-1939). He attended Jilore Primary School from 1940 to 1942; in 1943 he joined St John's Intermediate School, Kaloleni (then a boys' school and now renamed St John's Girls Kaloleni, in the present Kilifi County); he finally left this school in 1945. Between 1946 and 1949 he was at Alliance Boys' High School (the leading secondary school in Kenya to date), Kikuyu, Kiambu County. Between 1950 and 1951 he was at Kagumo Teachers' College, Nyeri County, for his training as a teacher. After the teacher-training, Kalume became a tutor at Ribe Teachers' College, now Ribe Girls' Secondary school, and taught at this school from 1952-1953. Later in May 1967, the teachers' college, which was sponsored by the Methodist Church, was moved from Ribe to Shanzu ${ }^{6}$ where it was amalgamated with Bura-Taita-Taveta, Mutune-Kitui, and Coast Teachers' College-Mombasa to form the present-day Shanzu Teachers' College. By 2015 Shanzu Teachers' Training College was located on a 45 hectare plot, 16 kilometres north of Mombasa Island, along Mombasa/Malindi Road near Shimo-La-Tewa Prison, Shimo-La-Tewa Secondary School and bordering ShimoLa-Tewa Primary School.

6 Shanzu Teachers' Training College is a public college for primary teachers' training. It also runs private courses such as Business Administration, Human Resources, Management, Information Technology, etc. 
Between 1954 and 1959 Kalume doubled as the head teacher of St John's Intermediate School, Kaloleni and as the supervisor of primary schools in the southern division of Kilifi district (later called Kaloleni division). From 1959 to 1962, he was the manager/supervisor of Anglican Church Schools in the presentday Taita-Taveta County. In those days, managers were, in terms of ranking, like the present-day County Education Officers (CEOs).

At this juncture, it is worthwhile to consider that Kalume's leadership qualities were first noted while he was a student. At Alliance High School, Kikuyu, Kiambu County (1946-1949), Kalume was appointed the captain of Livingstone House. As he left the school in 1949, Carey Francis, the headmaster, was deeply impressed by his leadership prowess, as he spoke openly about it. His house master, Mr J.S. Smith gave him a day book (diary) which is preserved by his family to date. It is in this diary that the researcher was able to extract a lot of information about Kalume's hand-written materials. Interestingly, Smith, a British national, also taught Kalume's second born son, Graham Tunje, when he later joined the school.

\section{Kalume's theological education and ordination}

While serving as the Principal of Kaloleni Boarding Primary School (1958), Kalume enrolled at Ridley Hall Cambridge, England, for a Bachelor of Divinity (BD Hons) as an external student. He was to study the London degree while basing himself at St Paul's United Theological College, Limuru (now St Paul's University); and indeed, St Paul's Limuru was allowed to offer the degree for the first time in its history that dates back to 1930. Earlier in 1961, Rev. J.O. Welsh became the principal of St Paul's United Theological College (Tunje 10:06:15). Rev. Welsh was a Presbyterian minister, ${ }^{7}$ unlike all the previous principals who were Anglicans.

Thus, in 1963, an External London University Bachelor of Divinity (BD) degree was inaugurated at St Paul's United Theological College, Limuru (Tunje 10:06:15). By then Kalume had already begun his studies (1958), but when St Paul's Limuru begun a degree programme in 1963, he continued with his studies. Hence, as he continued his external degree, he teamed up with two other African students, namely Elisha Wakube and John Crispin Onyango, who commenced their University of London BD studies. ${ }^{8}$ The idea of training Africans up to the degree level was essential because the three Missionary Societies, that is Church Missionary Society (CMS), Church of Scotland Mission (CSM) and the Methodist Missionary Society (MMS), were preparing to leave Kenya after the attainment of political independence.

In his well-kept diary since his Alliance high school days (1946-1949), Kalume, who completed his bachelor's degree in 1965 , recalls that he first travelled to

7 Provincial Unit of Research (PUR), From Rabai to Mumias: A short history of Church of the Province of Kenya 1844- 1994 (Nairobi: Uzima, 1994), 24.

8 Cole, K. Theological training in East Africa (Unpublished typescript, 1960), 24. 
England in 1958 so as to enrol as an external BD student. He was made an Anglican deacon by Archbishop Leonard James Beecher (1906-1987) in 1964, a year before he completed his London degree, while at St Paul's Limuru. From there, he assumed the title of a reverend. In turn, Beecher was an English-born Anglican Archbishop. He was the first Archbishop of the Province of East Africa, comprising Kenya and Tanzania, from 1960 to 1970 . He is also the last European missionary Archbishop in Kenya, as Festo Olang' took over as the first Archbishop of the Province of Kenya in 1970 when the Anglican province of East Africa was divided into Kenya and Tanzania provinces, each having its own archbishop. Beecher chose to take early retirement and settled in Kenya till his death in 1987, and he was buried at All Saints Limuru cemetery.

Following his return from the New York Theological Seminary (1966-1967) holding a Master's Degree in Religious Education in 1967, Kalume was immediately ordained as a full priest in 1967 at Mombasa Memorial Cathedral by the then Diocesan Bishop of Mombasa, Rt. Rev. Peter Mwang'ombe, who served as a bishop from 1964 to 1980. During the same period, 1967 and 1969, while working with the Bible Society of Kenya, he translated the New Testament from the original Greek language to Swahili. ${ }^{9}$ At the same time, he was a part-time lecturer in Homiletics at the then Coast Bible School, Makande, renamed Bishop Hannington Institute, and transferred to Buxton, Mombasa (Muramba 05:06:15). In his diary, he notes some of his overseas travels as including: a visit to India, New Delhi's 1961 conference of the World Council of Churches, as a delegate and/or representative of East Africa; his six months stay in England in 1958 as he enrolled as an external Bachelor of Divinity student; a visit to the Union Theological Seminary in New York (1965-1966); and the New York Theological Seminary (1966-1967). As noted earlier, it is in the latter that he obtained his Master's degree.

As a translator in the Bible Society of Kenya (1967-1969), operating from his Mombasa Memorial Cathedral house, Kalume was visibly present as a visiting preacher, seminar facilitator, and educator among other ecclesiastical duties (Mwang'ombe 18:06:15). In particular, he was voluntarily attached to St Paul's Rabai, St Emmanuel's Freretown and St Luke's Makupa. And between December 1969 and December 1974, he was the duly elected member of parliament (MP) for Malindi North, renamed Magarini.

9 The Swahili language, also known as Kiswahili, is a lingua franca of the African Great Lakes region and other parts of southeast Africa, including Tanzania, Kenya, Uganda, Rwanda, Burundi, Mozambique and the Democratic Republic of the Congo. The closely related Comorian language, spoken in the Comoros Islands, is sometimes considered a dialect. Although only around 15 to 50 million people speak Swahili as their first language, it is used as a lingua franca in much of southeast Africa. Estimates of the total number of Swahili speakers vary widely, from 60 million to over 150 million. 


\section{Kalume as a family man}

Kalume was joined in holy matrimony to Rebecca Florence Naswa d/o Andrea Chemiat from Chwele, Bungoma County, on Wednesday, 20 August 1952. The ceremony was conducted at St John's Anglican Church, Kaloleni, by the Rev. David Mzungu. Professionally, Rebecca was a nurse, and a mid-wife for that matter. Together they had nine children - six boys and three girls. That is: Onesmus Ngumbao (19532007), Graham Tunje (1954- ), Dorcas Nelima (1954- ), Kenneth Paul Mwambaru (1956- ), Andrew Peter Chango (1957-1994), Barnie Kambu (1959- ), Hilda Mnyazi (1959-2003), Tony Sirya (1961), and Irene Mary Amani Nazi (1963).

By the time of his death, he had bought several pieces of land that totalled about 350 acres, all in the present day Kilifi County. Of interest to note is that whenever he bought a piece of land, he never registered it under his name; rather, he registered all his pieces of land under the name(s) of his children. In other words, each piece would have a title deed featuring three or four children. After his demise, Rebecca (19262003) steered the family well - enabling some to acquire university degrees; and she was eventually collated an Anglican Canon in 1999 by the Mombasa Diocesan Bishop, Julius Kalu.

\section{KALUME AND THE NATIONAL ANTHEM}

As Kenya moved towards independence in early 1963, the colonial government tasked Graham Hyslop to assist the incoming government under Jomo Kenyatta in composing their national anthem. Hyslop was by then the inspector of music and drama from the Ministry of Education. Before then, Hyslop had been a great friend of Kalume since 1950s, as they would occasionally meet at the former schools where Kalume was head teacher, such as St Johns Intermediate School, Kaloleni, which was one of the leading schools in the country. Kalume's friendship with Hyslop reached its zenith in 1954 when he got his second son, whom he named Graham Tunje, in appreciation of the support that Hyslop had given him as a teacher and in his music career (Thuva 15:06:15).

According to Thuva (15:06:15), with whom they taught at one school, the four characters whom Hyslop called to help him compose the Kenyan National Anthem, are: Thomas Kalume, George Senoga Zake, Washington Omondi, and Peter Kibukosya (Thuva 15:06:15). Indeed, the task began in May 1963, with the formation of an advisory committee that comprised the above plus Richard Koskey and Samuel Waruhiu.

The anthem was to be in both English and Kiswahili and was meant to stir up a sense of patriotism and be no more than three verses. With the task defined, an anthem commission was thus formed to come up with several anthems for consideration. Indeed, some of the proposals that came up included the Zulu tune of Nkosi Sikelele Africa (God bless Africa), but after a long debate, Hyslop insisted that they stick 
to a Kenyan tune - which was finally found among the Pokomo of the present-day Tana River County. By then, they even thought the Nkosi Sikelele Africa was to be an entire African anthem (Chibule wa Tsuma 15:06:15). Indeed, this Pokomo lullaby went as follows:

Bee mdondo, bee, Bee mdondo bee [Oh insect bitter, oh insect bitter?] Akudo bee ni gani? [Who is disturbing the child?] Huenda hukawabige watu wamakoneah [Let's go and fight those disturbing you] Mwenziuyawa, ni nani? [The moon is clear, we shall see it clearly].

Considering that the tune had already been found from the solemn and prayerful lullaby of the Pokomo peoples, through Hyslop's efforts, Kalume was tasked with the job of the actual composition of the anthem. In other words, Kalume is the one who came up with the actual words as they are recited today. From time to time, the team of composers would visit him at St Paul's United Theological College, now St Paul's University, Limuru, as he pursued his studies. Thus, it is from St Paul's Limuru where Kalume composed the words of Kenya's national anthem, which was recorded in September 1963, and inaugurated at Uhuru Gardens on 12 December 1963 during the independence celebrations. ${ }^{10}$ Hence, as Kenyans listen to it, the memory of Kalume is reconstructed.

\section{KALUME AS A CHURCH LEADER}

Even before he was made an Anglican deacon by Archbishop Beecher in 1964, Kalume remained an influential and a devoted church leader. As a spell-binding speaker, Kalume continued to preach at St Andrews Malindi, Emmanuel church Jilore among other places, even when he was a member of parliament. Indeed, Archdeacon Nathaniel Mweri, the priest-in-charge, put him in the official preaching programme of the churches where he superintended (1970-1974).

As a member of parliament for Malindi North, Bishop Obadiah Kariuki of Mount Kenya Anglican Diocese, and his wife Lilian Wairimu (the daughter of senior chief Koinange), visited the Kalumes and his family in their beach house, Malindi; and stayed with them for four days (Tunje 10:06:15). During this visit by the most senior leader of the Anglican Church of Kenya, after Archbishop Festo Olang', Kalume took the opportunity to show them round his private and constituency projects. Again, during the December 1972 burial of the coastal kingpin, Hon. Ronald Ngala (1920-1972), the Hon. Rev. Kalume and Archdeacon Nathaniel Mweri conducted the burial ceremony, as George Konde Thuva led the choirs that consoled the people. Such gestures show that Kalume was not seen by his church as a deserter upon joining elective politics but as one whose territories had been expanded; as he did not cut ties with the former.

10 http://www.friendsofmombasa.com/ (accessed 10 June 2015). 


\section{KALUME'S JOURNEY TO POLITICS}

Kalume journeyed his way to elective politics from the late 1950s through to 1960 s, as a teacher, college tutor, school principal, as a church leader and as a chairman of various board memberships; and even as a chairman of various educational institutions in the locality. Indeed, he chaired boards for Kanamai Conference Centre, St Luke's Hospital-Kaloleni, and St John's Girls' Secondary School, among others. As he chaired the various boards, the locals could see a talented person. Coupled with this, their first member of parliament since Kenya's independence, Hon. Joshuah Malingi (1920- ), who was also the first Speaker of Kenya's Upper House (the Senate), appeared 'not to care' much as he by-passed his constituents without greeting them, as he drove off to the various destinations within and outside his constituency. In other words, he was not seen to be satisfactorily attending to the myriad of problems that befogged his constituents. Upon Kalume's return from the United States of America, while armed with a Master's Degree in Religious Education in 1967, all eyes were fixed on him as some preferred his elevation as an Assistant Bishop of Mombasa, while others thought of him as an MP (Muramba 05:06:2015). As the erstwhile Anglican Bishop of Mombasa (Peter Mwang'ombe) failed to post him owing to his 'high academic qualifications', the elders from Malindi North constituency needed him in Kenya's parliament. Was it Kalume's choice? Certainly not; for while being housed within the Mombasa Memorial Cathedral compound, around October 1968, a huge delegation from Malindi North constituency (renamed Magarini) came in buses and demanded to meet him there. As it turned out, Kalume was surprised to hear that theirs was not a pastoral issue but a political request that he becomes their member of parliament come December 1969. At first, he objected to the idea citing psychological preparations and lack of financial muscle as the key challenge to mounting a parliamentary campaign. In turn, they responded that they had already campaigned on his behalf. After being assured of success, he finally accepted the offer with a 'yes I will take it as service to God and humanity' that had them in tears of joy and excitement (Mangi 05:06:15). To some, Kalume did not campaign; to others, he did minimal campaigning throughout the vast constituency. He finally garnered $93 \%$ of the votes cast (3 401 out of 3657 ). It is from there that he moved from the city of Mombasa to Malindi, as the area's MP.

Upon his sweet victory, Rev. Kalume wrote on 6 December 1969 in his wellkept diary: 'I have been elected by people of Malindi North to be their representative in parliament with 3, 401 votes. [I have made history for] being the first African clergy in Kenya to be elected in the national assembly' (KD). Kalume was in fact the first African priest to not only join elective politics and subsequently win, but certainly not the first clergy in colonial and post-colonial Kenya to put religion and politics in one armpit. An explanation on this will suffice. 
First, a British Church Missionary Society (CMS) clergy, Archdeacon Walter Edwin Owen (1880-1945) ${ }^{11}$ of Kavirondo in the present-day western Kenya, had as early as 1921 formed a political party, Young Kavirondo Association (YKA). This made the European settler-farmers to call him derogatorily as 'Archdemon' for supporting the pleas of African labourers on their farms.

After succeeding Walter Chadwick as the Anglican Archdeacon of Kavirondo in 1918, Owen thus identified with the life and aspirations of the peoples of Nyanza. By then Kavirondo (western Kenya) was part of the Diocese of Uganda. He was tasked with the responsibility of organising the new, rapidly expanding church among the Luo, Luhya, and Kalenjin peoples. With Kenya having been declared a British colony in 1920, Owen founded the Kavirondo Taxpayers' Welfare Association (1922) to teach Africans how to run their own affairs. His political party, which was strengthened to become a welfare movement, taught Africans how to manage economic development. This led to the introduction of ploughs, watermills, new crops, and bookkeeping as the secret of planned development. Over the years, he educated many Luo and Luhya civic and political leaders. From the 1920s onward thus, he was outspoken in opposition to colonial legislation discriminating against Africans, such as forced labour and the hut tax. At the same time, he affirmed the right of missionaries to take part in local politics; but after 1935 he was held in suspicion by African radical politicians in western Kenya. As African nationalism heightened political activism in the 1940s, Owen retreated to ecclesiastical work, revised the Anglican Book of Common Prayer (Luo version) until his death in Limuru, near Nairobi, in 1945. ${ }^{12}$ Was Kalume influenced by Owen and his predecessors?

Another European missionary cleric who notably indulged in politics without losing his gospel constituency is John William Arthur (1881-1952), a medical missionary and Church of Scotland minister who served in British East Africa (Kenya) from 1907 to 1937. Following Scott's death in 1911, Arthur succeeded Rev. Dr Henry E. Scott as head of the mission and served in that capacity until 1937. He was known simply as 'Dr Arthur' to generations of Africans, and was appointed as a member of parliament as early as 1924, in the so-called Legislative Council of the Kenyan colony. Dr Arthur, who was once described as 'Africans' great friend' continued in his parliamentary position until his deep involvement in the female circumcision controversy in 1929-1930, in central Kenya, proved an embarrassment

11 Walter Edwin Owen (1878-1945) was assistant secretary in the CMS office in Belfast. He was accepted as a missionary in 1904 and ordained as a deacon in 1904 by the Bishop of London and as a priest in 1905 by the Bishop of Uganda. He served in Uganda for 14 years and then succeeded Walter Chadwick as Archdeacon of Kavirondo. He was a skilful administrator. His brother, Owen John Simpson was also a CMS missionary in West Africa.

12 For details, see David B. Barrett, 'Walter Edwin Owen 1878 to 1945, Church Missionary Society (CMS) Kenya/Uganda,' Gerald H. Anderson ed. 1998. Biographical dictionary of Christian Missions (W.B. Eerdmans Publishing Company, Grand Rapids, Michigan, 1998), 201-202. 
to the government and necessitated his resignation in 1929. ${ }^{13}$ Apart from being an active representative of African interests on the Legislative Council (1924-1926), Arthur was also on the Kenyan Executive Council (1928-1929). Like Kalume who came later and was concerned with health issues, gender disparities, land acquisition, national unity and societal cohesion plus education for all among other concerns, Dr Arthur was particularly concerned with problems of education, land ownership and labour reforms, and was involved in debates over the practice of female genital mutilation amongst the indigenous population. ${ }^{14}$ Arthur, who championed African education, is indeed one of the fathers of education in Kenya and the rest of Africa.

After Arthur's political tribulation, little is heard about clergy's indulgencies in parliamentary politics, save for the pockets of prophetic voices in central Kenya which, for instance, condemned the binding oath in central Kenya that sought to unite the Kikuyu community; and hence strengthen their unity as a political entity in 1969. The resultant oath ceremonies were prophetically dismissed by ecclesiastical leaderships as divisive to a young nation which needed unity of all ethnic groups. These onslaughts were led by Obadiah Kariuki, the erstwhile Diocesan bishop of Mount Kenya. Previously, in 1953, the Kiambu Ecumenical Meeting of church leaders, led by European missionaries, engaged in the politics of the day by condemning the politics of Mau-Mau. In turn, Mau-Mau was a guerrilla movement that was agitating for Kenya's freedom from the colonial government. In this Kiambu 1953 Meeting, the church leaders threatened to take up arms against the Mau-Mau rebels if the colonial government failed to do so. ${ }^{15}$ This again did not amount to engaging in elective politics. Did Kalume's case, of plunging into elective politics, open up a new socio-ecclesial trajectory that was to inform Kenya of the second half of the twentieth century and the twenty first century respectively? Was the new paradigm going to be buried with him or be re-ignited beyond his expectations?

\section{Kalume as an MP}

Kalume got into Kenya's second parliament, which had fierce critics of the new African government in early 1970. This government had been accused of poor handling of land issues that favoured the rich with its 'willing-buyer-willing-seller' policies. The poor ex-freedom fighters were to an extent seen as losers, and the collaborators were seen as winners. Hence debates in the second parliament were acrimonious, with the fiery Nyandarwa North MP, Josiah Mwangi Kariuki (popularly

13 Rosberg, C.G. and J. Nottingham, The myth of Mau Mau: Nationalism in Kenya (New York: Meridian, 1970).

14 Anderson, W.B. The Church in East Africa 1840-1974 (Dodoma: Central Tanganyika Press, 1977).

15 For details, see Julius Gathogo, 'Mau-Mau war and the church in Kirinyaga, Kenya: Accounting for the tension and conflict (1952-1960),' Studia Historiae Ecclesiasticae, December 2014, 40(2), $19-41$. 
called JM), threatening to sub-divide his pieces of land and give it to the poor if the government didn't do so. Similarly, the members of Kenya African Democratic Union (KADU) who had by then re-joined the ruling party, Kenya African National Union (KANU), were insisting on a federal system of government (Majimbo), rather than the republican system. There were also pockets of MPs in this cold war era (19171989) who were pro-East (communism), while the non-aligned Kenyan government was seen to be pro-West (capitalism). Apart from Kariuki, the second parliament had other fiery critics of the government such as Mark Mwithaga, Martin Shikuku, and Jean Marie Seroney, among others. In his maiden speech on 12 February 1970, where members of parliament were debating the President's speech in parliament that had been delivered the previous week, Kalume delivered a reconciliatory speech inviting his colleagues to be reasonable in handling matters of the house. He said thus:

Thank you, Mr Speaker. My name is Reverend Thomas Kalume from Malindi. I happen to have two constituencies, a geographical one of Malindi North and a spiritual one of this House and of Kenya. I want to assure the Mzee our President [Jomo Kenyatta] that the spiritual leaders of Kenya, that is: Christians, Muslims and African traditional leaders, pray for the long life of Mzee and for the highest standard of debate and conduct in the House to be maintained on a national level.

Kalume went on to say:

Now, going to the amendment, Mr Speaker, I think that it is very important that what the Hon. Member for Tinderet [Jean Marie Seroney] has said should be included in the Presidential Address. It is obvious that he cannot foresee everything that is going to happen during the session, but at least he should have a scheme for running this place so that we know roughly what we are going to expect [and what] will be discussed in this place. If anything that has not been foreseen before comes, we will include it even if it is not included in the [Presidential] Address. It is important to know that, because some of us who were teachers before know that you could not walk into a classroom and teach without having prepared your notes and have a scheme of work. In any department, you must have a syllabus and, therefore, this House should have that kind of guide so that we can know where we are heading to. Thank you, Mr Speaker [Fred Mati]. ${ }^{16}$

As a Member of Parliament, he displayed sobriety and decorum even during contentious debates, a tendency that pleased both the regional political kingpin, Hon. Ronald Ngala, and President Jomo Kenyatta. In particular, Ngala, who had known Kalume while they were both teachers in the 1950s, appreciated Kalume due to his passion for 'education for all', his improvements in agriculture, education, health and infrastructural facilities. On the other hand, Kenyatta appreciated Kalume right from the time he and others composed the Kenyan national anthem in the early 1960s. When he later joined parliament in 1969, Kenyatta used to invite him to State House, Mombasa, where they did not only enjoy roasted goat-meat but also enjoyed

16 Kenya National Assembly Official Record (Hansard), 6 February - 20 March 1970. 
Miji-Kenda traditional dances together. Kenyatta, who appears in Kalume's family photos, used to corrupt Kalume's name and fondly referred to him as Ka-a-rume (meaning the one from men or the young gentleman from the people). The same renaming was done to his other close coastal friend, Hon. Kassim Mwamzandi - the MP for Msambweni, whom Kenyatta fondly called Wamuthandi, meaning 'son of sparks' (Wamuthoni 14:06:15).

In his recollections, Graham (1954- ), Kalume's son, recalls a political rally which was addressed by the erstwhile coast regional political kingpin, Hon. Ronald Ngala. In this mid 1971 rally at Gongoni, both Ngala and Kalume spoke well of each other. In particular, Ngala who had contested the presidency in 1961 and 1963 but had his KADU party losing to Kenyatta's KANU in both elections, praised Kalume for seemingly improving agriculture, education, health and infrastructural facilities within a short time (1969-1971). He told the audience that if the constituency needed a genuine leader, then Kalume was the best one for Malindi North (Tunje 10:06:15).

\section{Kalume and the 1974 general elections}

Kalume's prestigious beach house, in the Silver Sands Resort Centre, became a political concern during the December 1974 general election campaigns. In particular, his opponents exploited the ujamaa (communal) nature of the Giriama society to show that he was a capitalist who had lost touch with the rank-and-file of the constituency that he had represented in parliament for five years. How did he get all these monies to 'acquire such a prestigious house when $99 \%$ of us are living in thatched houses? And why does he keep a tough dog that makes it hard for us to access him at his own house? Why only meet him in his office and after church service? Why is there an inscription, "Be aware of Fierce Dog" on the gate of his house?' his opponents in the political divide would ask loudly in order to incite the masses against him (Mangi 05:06:15). Certainly, as a member of parliament, he needed security at all costs; hence a tough dog and a security officer to guard the compound were necessary. The fact of the matter was that Kalume got his prestigious beach house from a presidential decree. The then President Jomo Kenyatta had instructed the Ministry of Land and Settlement to allocate it to him so as to enable him to serve better. This beach house decree came after a request that he (Kalume) had made following his electoral triumph in 1969.

Another critical concern that made Kalume lose his Malindi parliamentary seat is due to divisive clan politics and negative ethnicity. Indeed, two years before the December 1974 elections, supporters of Joseph Kasena Yeri - a trade unionist then and the person who eventually ousted Kalume - had begun to exploit the clan and ethnic divisions therein. First, Kalume was from the minority Kambe ethnic group of the larger Miji-Kenda nation, in a constituency that is largely dominated by the Giriama ethnic group. Second, his marriage to Rebecca Naswa, a Bukusu from the 
larger Luhya nation of western Kenya, was interpreted and politicised maliciously by his opponents as an insult to the local Giriama and the larger Miji-Kenda women. How could he share his largesse with a person from the distant lands?.

As it turned out, Kalume's quest for 'education for all', a goal shared in the Millennium Development Goals (MDG) and the Sustainable Development Goals (SDGs) of the $21^{\text {st }}$ century, also became one of the factors that led to his political Waterloo. ${ }^{17}$ Why? Kalume 'over concentrated' on the concern for education 'while the people of Malindi North felt that their main problem was water, not education' (Tunje 10:06:15). As the October-November 1974 electioneering and campaigns were gaining momentum, some could be heard saying openly: 'Why does Kalume's leadership construct schools in a desert, while our concern is water?'

Again, when his constituents went into office to seek financial hand-outs so as to pay fees for their children, Kalume would lecture to them about how to manage their little resources prudently and avoid relying on relief food, donors, and/or hand-outs from individual rich people. He would also advise them to sell part of their livestock and/or farm produce. This refusal to give hand-outs was meant to empower them and indeed make them appreciate their many assets and eventually avoid dependency syndromes. In so doing, Kalume hoped it would wipe out the dependency syndrome completely in the society. Unfortunately, this made him unpopular with a section of his constituents who saw the legislator's role as that of 'a week-end donor'. Like the proverbial kicks of a thankless donkey, they sent him home come December 1974. Certainly, this marks both his strengths and weaknesses. Couldn't he sense it coming and adjust accordingly? Did he fail to adjust from ecclesiastical to political stewardship? Was he too ignorant regarding his Muslim voters and did he fail to address their concerns?

Upon losing the December 1974 general elections, Kalume continued with his church ministry as a visiting speaker in churches and schools, despite having suffered a heart disease (in 1972) that had stabilised after being handled by a Mombasa citybased physician, Dr J.B. Okanga. Following his electoral defeat, his heart troubles reemerged. Hence he would miss out on some occasions from time to time. Since then, he was frequently in hospital. As he conducted the burial ceremony for a European friend in the Malindi Christian graveyard, on 15 March 1975, he collapsed dead to the bewilderment of the congregants. This is after he had just uttered the liturgical words, 'from dust to dust, we return' (Muramba 05:06:15).

17 Waterloo is a small town a few miles south of Brussels, Belgium. The Battle of Waterloo, as it has come to be known, is always included on lists of battles that changed the course of history. Napoleon was considered one of the greatest generals ever, yet he is often defined by this one terrific loss at the end of his career. Indeed, the Battle of Waterloo was fought on Sunday, 18 June 1815 , near Waterloo in present-day Belgium, then part of the United Kingdom of the Netherlands. A French army under the command of Napoleon was defeated by the armies of the Seventh Coalition, comprising an Anglo-allied army under the command of the Duke of Wellington, who combined with a Prussian army under the command of Gebhard von Blücher. 


\section{KALUME'S RECONSTRUCTIVE PHILOSOPHY}

Philosophically, Kalume propounded the view that the transformation of the community can best be done through education in concert with the Christian faith. As in Plato's Republic, where he held that the ideal city-state is best ruled by philosopher-kings, or people who can genuinely and adequately philosophise (The Republic, 5.473d), Kalume held strongly that only highly educated people can lead the Kenyan nation, and the rest of tropical Africa. He also stressed that their education must be spiced with the gospel of Christ. Was he reading from the same script as Mahatma Gandhi, the Indian nationalist of Hindu faith, who appreciated Christ's teaching and influenced the civil rights leader, Martin Luther King (19291968 ) in his non-violence movement of the 1960s in USA? Kalume also struck a working chord with the Brazilian educationist, Paulo Freire (1921-1997) who held that all people can learn, and therefore education should be for all; and dispelled the notion that the illiterate are too ignorant to learn. Rather, he espoused his 'Education for critical consciousness' philosophy as a direct challenge to the elites in society, who usually tend to believe that the only privilege of the grassroots is on the terms of 'assistentialism'. ${ }^{18}$ That is, giving the wrong impression that the government owned all the economic resources in the country and could choose to give assistance only to those they wished. In light of this, Kalume's legacy, especially as an MP, is characterised by the establishment of schools and colleges; university education; and setting bursaries for the less fortunate families so as to promote education for the greatest number.

Another dimension of Kalume's philosophical outlook is that he used to view Jesus Christ as the greatest politician who has ever lived. Though a member of the pietistic East African Revival Movement (also called Balokole or the 'saved ones'), Kalume was deeply against those who say that politics is a dirty game, as 'the welfare of the people of God cannot be dirty' (Tunje 10:06:15). His dream was to have clean and honest politicians who necessarily shun corruption. As noted above, he was the first African clergyman to serve as a parliamentarian, though a European missionary by name of Rev. Dr Arthur had been nominated in 1924 by the colonial government. Upon Kalume's electoral defeat in December 1974, the then President of Kenya (Jomo Kenyatta), like the biblical David who mourned his good general Abner when he was killed by a rival army general, Joab (2 Samuel 3), lamented his defeat. Reportedly, Kenyatta uttered obscenities at the 'bad' voters who had dethroned such an educated and far-sighted Kenyan, and whose religious background was a plus to the sobriety of the young nation. It is from there that he nominated Bishop Lawi Imathiu of the Methodist church as a member of parliament, from 1975 to 1979 . Since then, a number of clergy have plunged into politics either as nominated or as elected MPs. In

18 Freire, Paulo. Politics and education (Los Angeles, UCLA Latin American Center Publications, 1998). 
particular, Archbishop Stephen Oluoch Ondiek (1945-2011) of an African Instituted Church, Legio Maria, was competitively elected as the MP for Ugenya in 1983. Other clerics who followed in Kalume's trajectory include: Prophetess Mary Wajiru of Kinangop, 1992-97; Bishop Allan Njeru of Mwea, 1992-97; Rev. Morris Dzoro of Kaloleni, 2002-2007; Rev. Moses Akaranga of Sabatia Constituency, 2002-2007 and later the Governor of Vihiga, 2013-2017; Bishop Margaret Wanjiru Kariuki of Starehe, 2007-2012; Rev. Mutava Musyimi of Gachoka, now Mbeere South, 20072017; and Bishop Robert Mutemi Mutua, 2013-2017, as a Wiper Party's nominated MP among others.

Nevertheless, Kalume's foresightedness in the dark and ignorant histories of Kenya could not be understood then. Clearly, he was ahead of his time, and indeed a societal model in various facets of life, notwithstanding his noted weaknesses. Conversely, he failed to contextualise his religio-political discourses by largely failing to balance the two. In a society where some were ardent adherents of African indigenous religion, and where others were Christians and/or Muslims, Kalume did not have to be seen to tilt the balance unapologetically towards the church. To some, his office was in the church; hence he was more of a church leader than a parliamentarian. This may explain his loss, though with a small margin.

\section{CONCLUSION}

In conclusion, Thomas Kalume was many things to different people. To the church, he was a Balokole (brethren) in the East African Revival Movement, whose territories had been expanded by God so as to serve both 'Wheat and Tares' - the society - as the day of the Lord approached (Hebrew 10:25b). To others in the church, he was an organist who played best in the church choir, a great preacher and a public theologian who used every opportunity to educate the masses on theo-ethical issues. To the rest of society, he was a fine footballer, polished orator, musician and a politician, champion of modern development and a great family man. He was a pragmatist politician who called a spade a spade, even when the political risk of rejection was beckoning. He was a man whose set task to empower the rank-and-file of society through the medium of education was at first misunderstood, but later understood years after he was free at last. To others, Kalume is the great Kenyan whose imprints will remain even after the promulgation of Kenya's new constitution on 27 August 2010 , for the words in the national anthem were not altered whatsoever. Hence, the anthem remains Kalume's prayer as well as Kenya's prayer across the centuries: 'O God of all creation; bless our land and nation; justice be our shield and defender; may we dwell in unity, peace and liberty; plenty be found within our borders.'

Indeed, the memory of Thomas Johnson Kuto Kalume has been celebrated and/or reconstructed half a century after Kenya's independence to indicate that his concerns remain in the national agenda. As a school teacher-turned-clergyman- 
turned-politician and a farmer owning acres of land, and as a person who called himself 'a pioneer African clergy' in 'electoral victories of Kenya's parliamentary history', Kalume epitomises the modern-day Africa. That is, a society that has to necessarily multi-task (or is it an 'all-inclusive approach?') in order to reap huge benefits, without losing her identity and image. As minerals and petroleum products are being discovered in the $21^{\text {st }}$ century Kenya, and as the economy sets out to provide free primary, secondary and university education, the memory of Kalume's vision and prayer for prosperity is reconstructed. As Africa wrestles with terrorism, negative ethnicity, divisive and genocide-driven politics, xenophobia and democratic impediments, Kalume's prayer for 'unity, peace and liberty' becomes not only a Kenyan prayer but a prayer for the wider African constituency across the generations.

\section{REFERENCES}

Anderson, W.B. 1977. The church in East Africa 1840-1974. Dodoma: Central Tanganyika Press.

Barrett, D.B. 1998. 'Walter Edwin Owen 1878 to 1945, Church Missionary Society (CMS) Kenya/ Uganda.' In Biographical dictionary of Christian Missions, edited by Gerald H. Anderson. Grand Rapids, Michigan: W.B. Eerdmans Publishing Company.

Cole, K. 1960. Theological training in East Africa. Unpublished typescript.

Gathogo, Julius. 2014.'Mau-Mau war and the church in Kirinyaga, Kenya: Accounting for the tension and conflict (1952-1960),' Studia Historiae Ecclesiasticae, 40(2): 19-41.

Gilbert, E. and Reynolds, J.T. 2008. Africa in world history: From prehistory to the present. Pearson Education.

Gitari, David. 2014. Troubled but not yet destroyed: Autobiography of Dr David M. Gitari, Retired Archbishop of the Anglican Church of Kenya. McLean: Isaac Publishing.

Kalume, Thomas. Diary (KD) that keeps information about his lifetimes from 1925 to 1974. Kenya National Assembly Official Record (Hansard), 6 February - 20 March 1970.

Freire, Paulo. 1998. Politics and education. Los Angeles: UCLA Latin American Center Publications.

Preucel, Robert W. and Mrozowski, Stephen A. 2011.Contemporary archaeology in theory: The new pragmatism. John Wiley \& Sons.

Provincial Unit of Research (PUR). 1994. From Rabai to Mumias: A short history of Church of the Province of Kenya 1844-1994. Nairobi: Uzima.

Rosberg C.G. and Nottingham, J. 1970. The myth of Mau Mau: Nationalism in Kenya. New York: Meridian.

UNESCO 2008. 'Canadian fossil park, an Icelandic volcanic island and archipelago in Yemen among sites added to UNESCO World Heritage List,' UNESCO, 7 July 2008 (accessed 14 June 2015). 


\section{INTERVIEWS}

Kuto, John Gamoyoni. Interview 5 June 2015 at Gongoni, Malindi.

Mangi, Morris. Interview 5 June 2015 at Marikebuni, Malindi, Kilifi County.

Muramba, Justin Masha. Interview 5 June 2015 at Gongoni, Malindi,Kilifi County.

Mwang’ombe, Newman. Interview 18 June 2015 at Kenyatta University, Mombasa campus.

Mwaro, Alphonse Baya. Interview 7 June 2015 at Changamwe, Mombasa County.

Tunje, Graham Kalume. Interview 10 June 2015 at Mianzini village, Kambe location, Rabai subCounty, Kilifi County.

Thuva, George Konde. Interview15 June 2015 at Kenyatta University, Mombasa campus.

Tsuma, Anderson Chibule Wa. Interview 15 June 2015 at Kenyatta University, Mombasa campus.

Wamuthoni, Patrick Gathimba. Interview 14 June 2015 at Chege's Café, Changamwe. 